\title{
Particleboard from coir pith
}

\author{
E. Ahmed ${ }^{1}$, A. K. Das ${ }^{1,2 *}$, M. O. Hannan ${ }^{1}$ and M. I. Shams ${ }^{1,3}$ \\ ${ }^{1}$ Forestry and Wood Technology Discipline, Khulna University, Khulna-9208, Bangladesh \\ ${ }^{2}$ Pulp and Paper Technology, Asian Institute of Technology, Klong Luang, Pathumthani-12120, Thailand \\ ${ }^{3}$ Research Institute for Sustainable Humanosphere (RISH), Kyoto University, Japan
}

\begin{abstract}
This study aimed to find out the feasibility of coir pith as a raw material for particleboard production. Considering particle size, an attempt was taken to produce resin bonded coir pith particleboard and binder-less coir pith particleboard as well. The physical and mechanical properties of the board were examined. The particleboard made from medium size particle showed the best performance in aspect of properties. The particleboards made with 16\% Melamine Urea Formaldehyde (MUF) had better product quality than binder-less coir pith board. The MOR, MOE, TS and IB were respectively 24.65, 2398, 22.55 and $1.52 \mathrm{~N} / \mathrm{mm}^{2}$. Coir pith board may be a sustainable, cheap and durable building and packaging materials and timber substitute.
\end{abstract}

Keywords: Coir pith; Melamine Urea Formaldehyde (MUF); Modulus of Elasticity (MOE); Modulus of Rupture (MOR); Water absorption; Thickness swelling

\section{Introduction}

The demand for composite wood products, such as plywood, oriented strand board (OSB), hardboard, particleboard, medium-density fiberboard, and veneer board products has recently increased substantially throughout the world (Youngquist, 1999; Sellers, 2000). Properties of particleboard made from saw dust, rice husk, bamboo wastage, dhaincha, jute stick and Areca catechu were studied by investigators (Sarker et al., 2012; Das et. al., 2012; Islam et. al., 2013; Zaman et al., 2013; Ghosh et al., 2015). Studies were conducted on medium density fiberboard (MDF) of bagasse, banana plant stem, mid-rib of banana plant leaf, rice straw and kenaf (Das et al., 2014; Rashid et. al., 2014; Islam et al., 2014; Das et al., 2015). Investigation was also carried out to find out the properties of plywood made by ghora neem and raj koroi (Rahman et al. 2013; Rahman et al. 2014). According to a report from Food and Agricultural Organization (FAO) of the United Nations, the worldwide demand of particleboard panels was $56.2 \mathrm{Mm}^{3}$ in 1998 (Youngquist and Hamilton, 2000). The demand for particleboards in the sectors of housing construction and furniture manufacturing has continued to increase (Sellers, 2000). The feasibility of using fast-growing trees and agricultural residues as raw materials for particleboard production has been explored by a number of researchers.

Coir pith is a byproduct of coir industry. $\mathrm{pH}$ of coir pith is acidic in nature (Maragatham and Samuel, 2010). The coconut husk comprises roughly $30 \mathrm{wt}$ \% coir fibers and 70 wt.\% pith, which have to be separated for traditional coir fiber applications in woven carpets, ropes, brushes and matting (van Dam, 2002). This can be achieved by retting procedures or mechanical decortications. The pith residue contains $24.1 \%$ lignin, which is used as a melt-able binder for the coir fibers acting as a strong and stable resin-like adhesive (van Dam et al., 2004). Extrusion, steam explosion and milling are three processing routes from husk to boards without addition of synthetic binder have been evaluated (van Dam et al., 2003).

The market potential of coir pith particleboard for timber replacement is impressive. The world production of coir fibers is estimated above 400,000 tons annually. The cost calculation for the production of particleboard is composed of $34 \%$ glue and $32 \%$ wood (66\% raw materials costs), $24 \%$ labor and 10\% energy (van Dam et al., 2003). So the relative

*Corresponding author. e-mail: atanu03ku@yahoo.com 
high costs for the glue can be excluded in the production of binder-less coir-boards. The overall costs of the coir-board production could therefore be substantially lower than for the cheapest building boards in the market. Therefore it is likely that the price performance ratio of the novel building boards will cover the market potential of a broad range of wood products and building panels. Coir pith particleboard may be a sustainable building materials and timber substitute as well.

This study was conducted to evaluate the potentiality of coir pith as binder-less particleboard production as well as MUF bonded coir pith particleboard. The effects of particle size and amount of resin content on the particleboard properties were assessed.

\section{Materials and methods}

The coir pith was collected as industrial residue from the SMART coir mattress industries Co. Ltd., Kashiani, Gopalgonj, Bangladesh. Melamine Urea Formaldehyde (MUF) resin (the amount of melamine was 7-10\%) of $52.06 \%$ solid content was used as the adhesives for making the particleboards. MUF was from Fisher Scientific Chemical Co. The coir pith was oven dried to attain about $7 \%$ of moisture content. The coir husk was separated into coir pith and coir fiber by milling with a hammer mill. (Model C269OYB, Franklin Co. Inc., Buffton, IN). The resulting particle size was 10-20 (small), 20-40 (medium), and 40-60 (large) mesh. The coir particles were stored in a chamber to maintain a constant $7 \% \mathrm{MC}$ (Moisture Content) at $52 \% \mathrm{RH}$ (Relative Humidity) and $21 \pm 1^{\circ} \mathrm{C}$ until they were used.

Particleboards were made following the procedures outlined by Youngquist (1999). MUF with 1\% (w/w) ammonium sulfate based on the solid content of the UF as a curing catalyst was mixed with coir particles at room temperature $\left(20-22^{\circ} \mathrm{C}\right)$ for $8 \mathrm{~min}$ manually. The particles were then pre-pressed into a $2 \mathrm{~cm}$ single layer mat in a $22.8 \mathrm{~cm} \times 22.8 \mathrm{~cm}$ coir mold for MUF bonded coir pith particleboards. The mat was formed in a similar way for binder-less coir pith particleboards. The pre-pressed mats were pressed for $5 \mathrm{~min}$ in a hot press (Model 8931 Auto "M", Carver, Inc. Wabash, IN) for both types of board. The temperature and pressure were con- trolled at $160^{\circ} \mathrm{C}$ and $3 \mathrm{~N} / \mathrm{mm}^{2}$, respectively for MUF bonded board whether temperature and pressure were $205^{\circ} \mathrm{C}$ and $5 \mathrm{~N} / \mathrm{mm}^{2}$ for binder-less board. The MC of finished particleboards was adjusted to $3.9 \%$ by conditioning the particleboards for $72 \mathrm{~h}$ in a cabinet where $\mathrm{RH}$ was maintained at $65 \%$ by using a saturated $\mathrm{CaCl}_{2}$ solution and the temperature was controlled about $20^{\circ} \mathrm{C}$. The conditioned particleboards were trimmed off about $2 \mathrm{~cm}$ around the edges to avoid edge effects and then cut into various sizes for the property evaluations. The density was controlled by the proposal of Yossifov (1988). The density and thickness of finished boards for both types were $750 \mathrm{~kg} / \mathrm{m}^{3}$ and $0.10 \mathrm{~cm}$, respectively. The 20-40 mesh particles were used for making the rest of particleboards for determining the effect of MUF percentage considering the best quality of this particle size for study.

Physical and mechanical properties were determined according to ASTM (D1037-99) (1999). The size of the sample for modulus of elasticity (MOE) and modulus of rupture (MOR) were $15.2 \mathrm{~cm} \times 3.8 \mathrm{~cm}$ and $17.8 \mathrm{~cm} \times 5.1 \mathrm{~cm}$, respectively. Sample size was $5.1 \mathrm{~cm} \times 5.1 \mathrm{~cm}$ for internal bond strength (IB), water absorption (WA), thickness swelling (TSW) and tensile strength (TS) measurement. The mechanical properties were determined using a Hydraulic universal testing machine (Model 100, Class 1; Made in Time group Inc, The People Republic of China) with the speed of movable crosshead set at $2 \mathrm{~mm} / \mathrm{sec}$ for TS and $1 \mathrm{~mm} / \mathrm{sec}$ for MOE, MOR and IB.

\section{Results and discussion}

Effect of particle size on mechanical properties of binderless and MUF bonded particleboard

Board made from medium size coir pith particle showed the best performance for both binder-less and MUF bonded particleboard. The highest MOE, MOR, TS and IB for MUF bonded particleboard were 2398, 24.7, 22.6 and 1.52 $\mathrm{N} / \mathrm{mm}^{2}$, respectively (Fig. 1 and Fig. 2). On the other hand, MOE for binder-less particleboard was $2108 \mathrm{~N} / \mathrm{mm}^{2}$, MOR $20.3 \mathrm{~N} / \mathrm{mm}^{2}$, TS $9.5 \mathrm{~N} / \mathrm{mm}^{2}$ and IB $1 \mathrm{~N} / \mathrm{mm}^{2}$ (Fig. 1 and Fig. 2). Small (10-20 mesh) and large (40-60 mesh) particle produced poor result for all properties (Fig.1 and Fig. 2). MOR and IB for binder-less particleboard of oil palm trunk were 
5.3 to 8.8 and 0.65 to $1.10, \mathrm{~N} / \mathrm{mm}^{2}$ (Lamaming et al., 2014). According to Saari et al. (2014), MOR 4.9 to $23.3 \mathrm{~N} / \mathrm{mm}^{2}$ and IB 0.50 to $1.40 \mathrm{~N} / \mathrm{mm}^{2}$ for binder-less particleboard made from oil palm trunk. The mechanical properties except TS of binder-less board were close to MUF bonded board for medium size particle. Both types of board followed the standard ANSI/A208.1 (2009). The mechanical properties of binder-less board were also better than previous study. soaking in water (Fig. 3). WA of binder-less board for medium size particle (20-40 mesh) was 51.2\% and TSW $24.1 \%$ (Fig. 3). MUF bonded board for medium size particle showed that WA was $42 \%$ and TSW $20.9 \%$ (Fig. 3). MUF bonded board showed lower WA and TSW than that of binder-less board (Fig. 3). Yang et al. (2003) found that WA and TSW were above 80 and $60 \%$, respectively for solid wood particle. TSW and WA for binder-less particleboard of
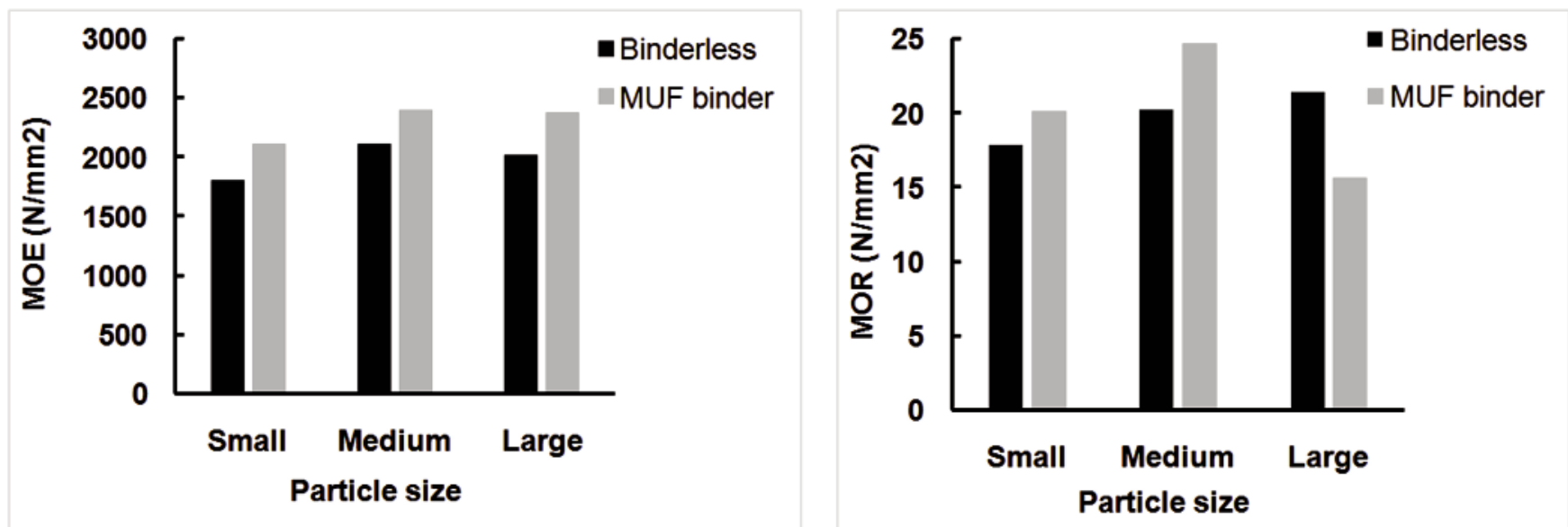

Fig. 1. Effect of particle size on MOE and MOR of binder less and MUF bonded coir pith particleboard
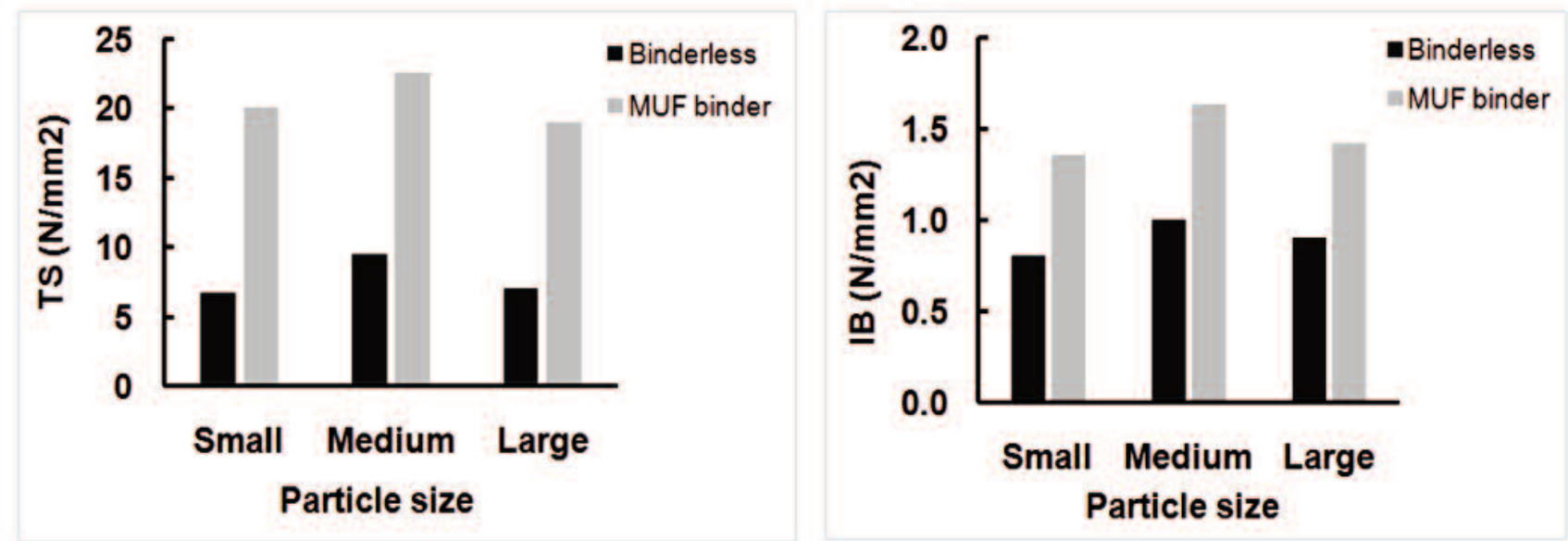

Fig. 2. Effect of particle size on TS and IB of binder less and MUF bonded coir pith particleboard

Effect of particle size on water resistivity of binder-less and MUF bonded particleboard

The particleboard made from medium size particle had the lowest water absorption (WA) and thickness swelling (TSW) for both binder less and MUF bonded board after 24 hours oil palm trunk were 22.7 to 39.6 , and 72.0 to 90.6 , respectively (Lamaming et al., 2014). Saari et al. (2014) found that TSW and WA for binder-less particleboard of oil palm trunk were 32.0 to 59.3 and 58.7 to $100.4 \%$. Binder-less coir pith particleboard made from medium size particle showed lower and higher value of WA and TSH in comparison to previous 

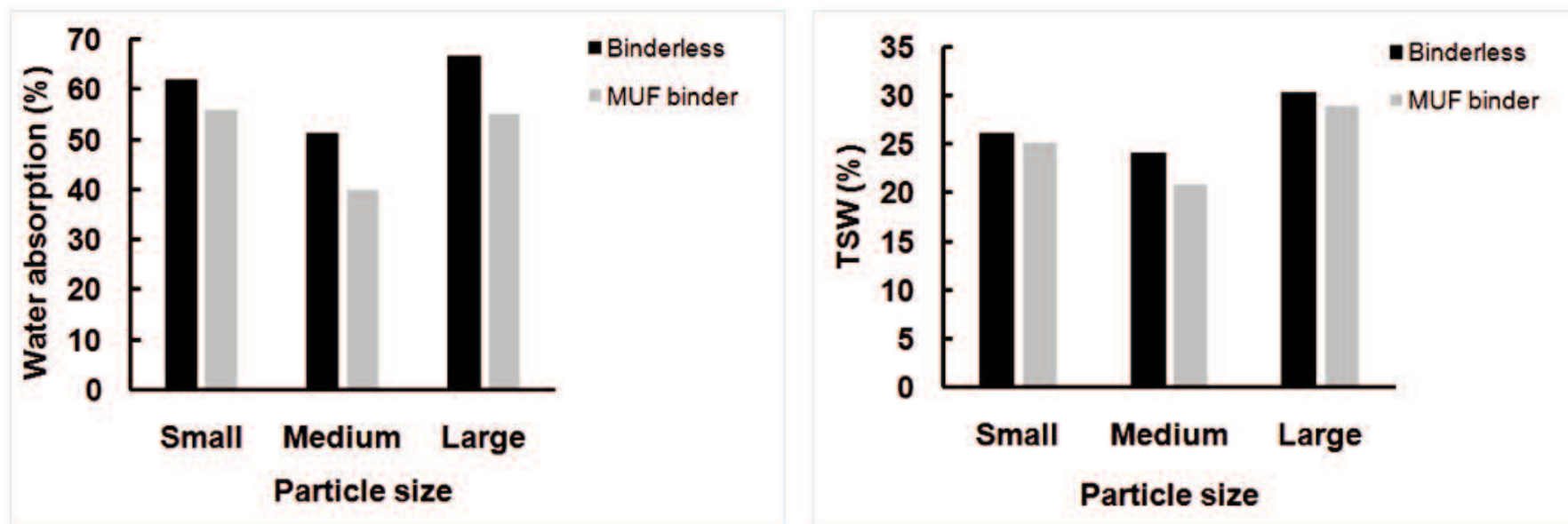

Fig. 3. Effect of particle size on WA and TSW of binder less and MUF bonded coir pith particleboard

study (Yang et al., 2003; Lamaming et al., 2014; Saari et al., 2014).

Effect of percentage of MUF adhesives on mechanical properties

The 16\% MUF bonded particleboard prepared from medium size particle had higher MOE, MOR, TS and IB than that of 7\% MUF bonded particleboard (Fig. 4 and Fig. 5).

According to ANSI A208 1 (2009), MOE, MOR and IB followed the standard for MUF bonded particleboard for all percentage of MUF. Juliana et al. (2012) observed MOR,

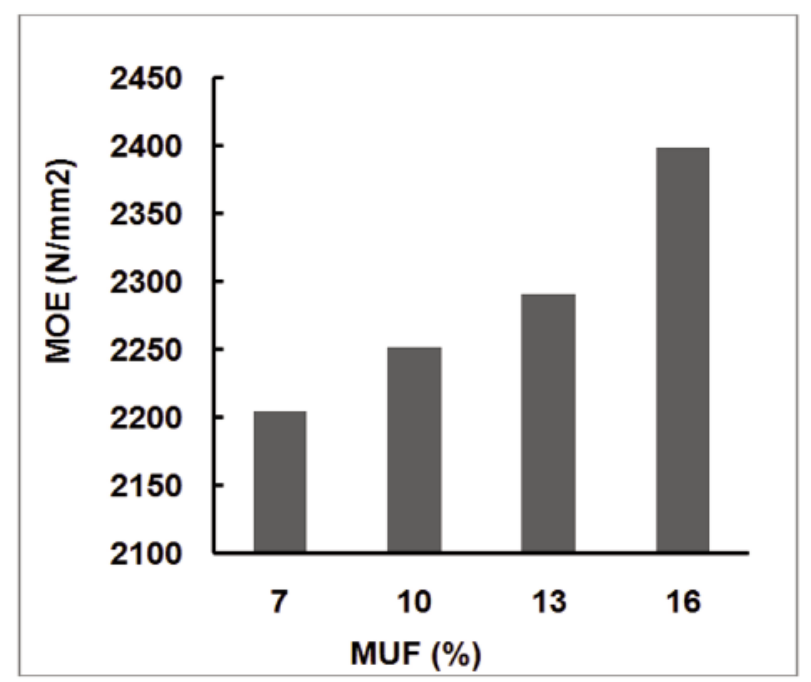

MOE and IB 11.5 to $15.7,1365$ to 2438 and 0.09 to 0.44 $\mathrm{N} / \mathrm{mm}^{2}$, respectively for kenaf and rubber wood particleboard. MOR, MOE and IB for oil palm trunk were 5.23 to $7.09,839$ to 863 and 0.67 to $1.05 \mathrm{~N} / \mathrm{mm}^{2}$, respectively (Jumhuri et al., 2014). MOE, MOR, TS and IB of all percentage of MUF bonded particleboard for medium size particle were higher than oil palm trunk, kenaf and rubber wood.

Effect of percentage MUF adhesives on water resistivity of coir pith board

The water absorption (WA) of all boards of different percentage of MUF after 24 hours soaking was in the range 40 to

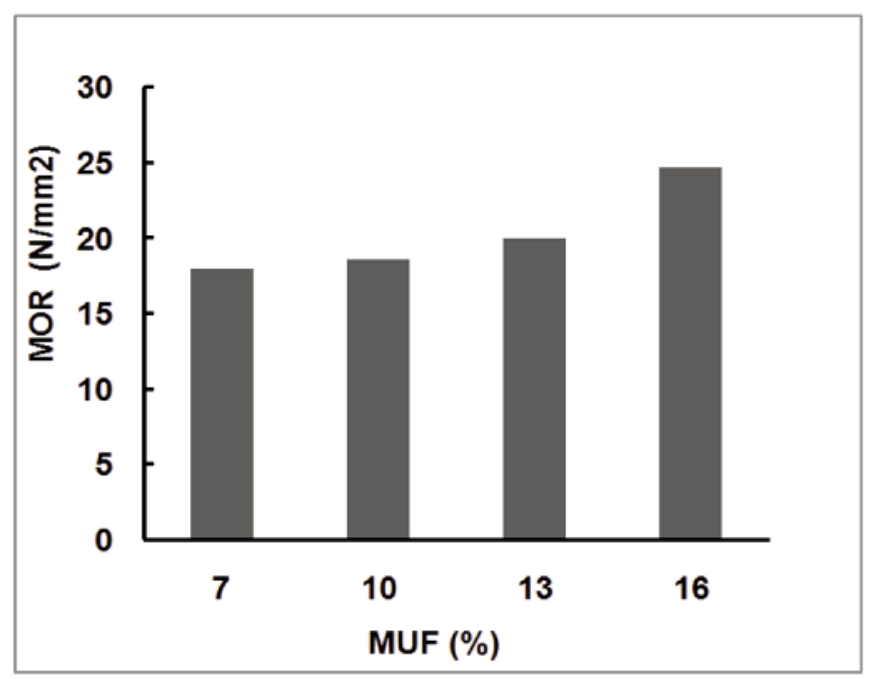

Fig. 4. Effect of percentage of MUF on MOE and MOR of coir pith particleboard 

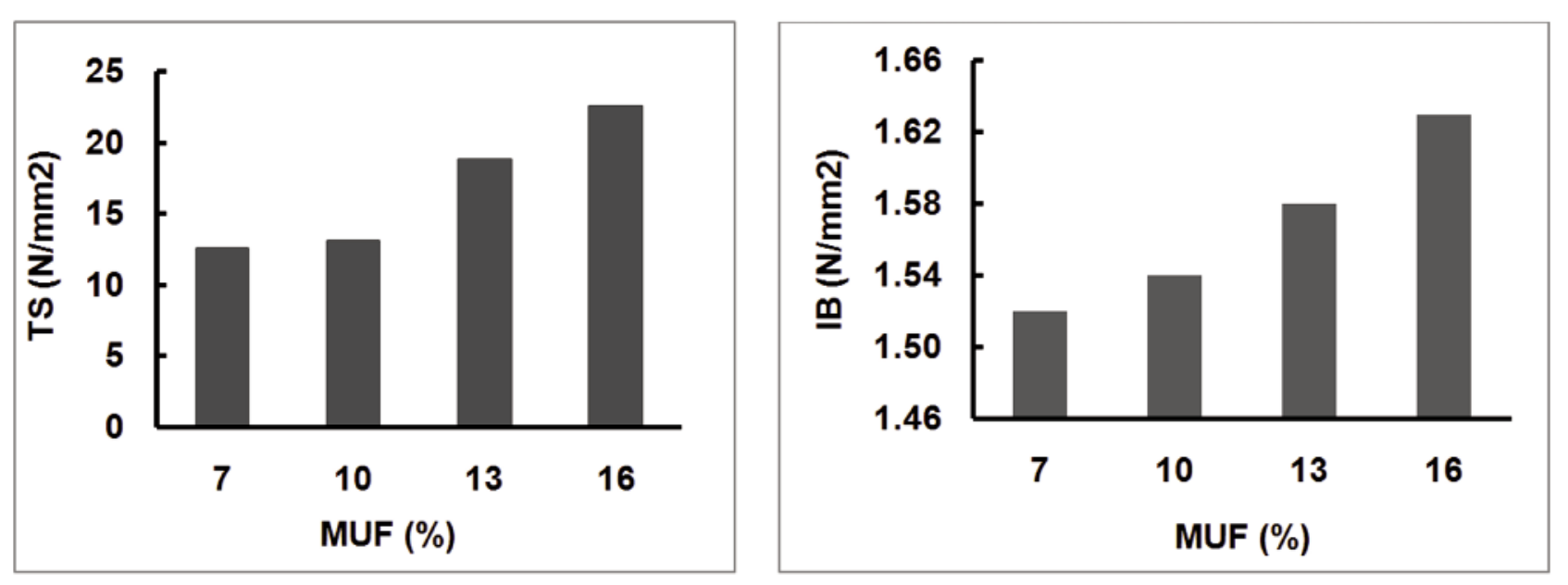

Fig. 5. Effect of percentage of MUF on TS and IB of coir pith particleboard

$52 \%$ whether thickness swelling (TSW) was 23.0 to $29.5 \%$ (Fig. 6). This was substantially lower as compared with those of the wood-based composites $(70 \%)$ and solid woods (80\%) (Yang et al., 2003). The thickness swelling of all boards showed below 30\% (Fig. 6). The thickness swelling

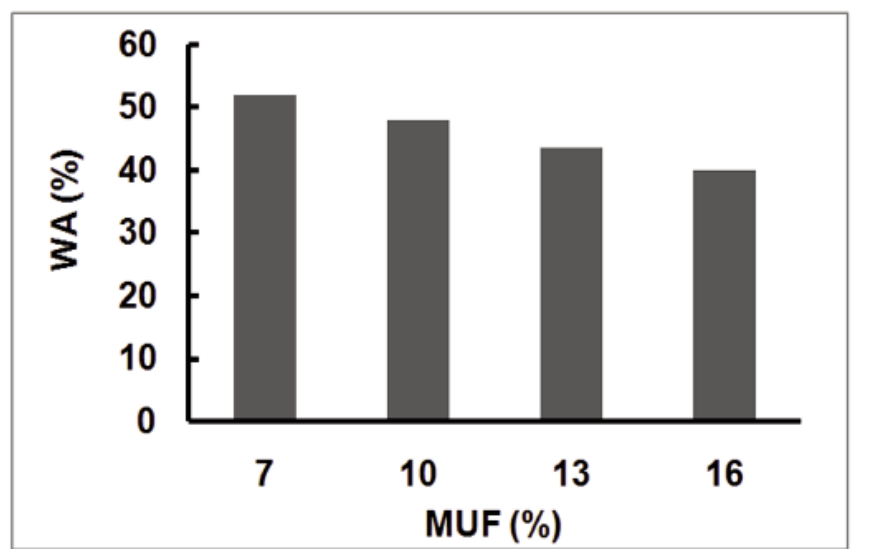

respectively, above 120 to 140 and 53.51 to $65.95 \%$. WA and TSW were lower than that of previous studies.

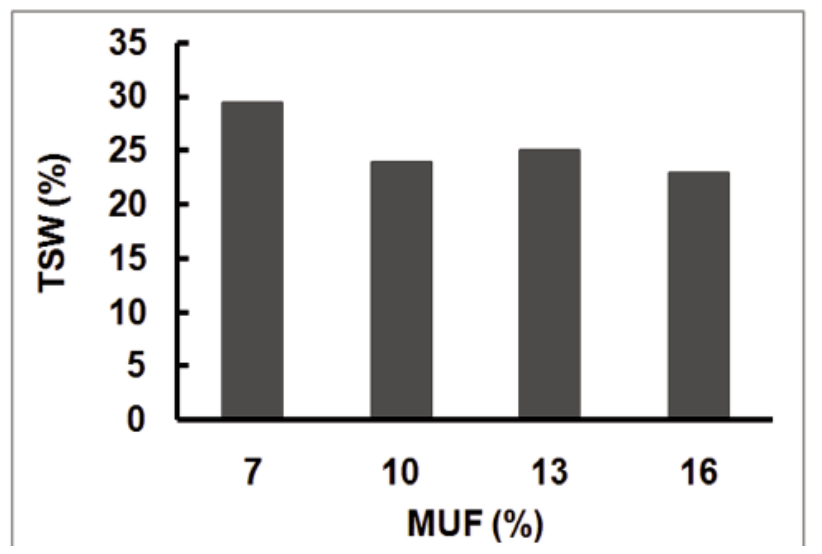

Fig. 6. Effect of percentage of MUF on WA and TSW of coir pith particleboard

of 7\% MUF bonded particleboard was still larger than that of $16 \%$ MUF bonded particleboard. The thickness swelling of $16 \%$ MUF particleboard was still higher than that allowed by the U.S. Standard ANSI/A208.1. Kenaf and rubber wood particleboard showed that water absorption and thickness swelling were 77 to 179 and 28 to $67 \%$, respectively (Juliana et al., 2012). Jhumuri et al. (2014) observed that water absorption and thickness swelling for oil palm trunk were

\section{Conclusion}

Board made from medium size particle showed the best performance for binder less and MUF bonded board. MUF bonded board showed the best performance when 16\% MUF was used. The mechanical properties followed the standard and showed better quality than previous study as well. WA and TSW were also less than previous study for both types of board. So coir pith may be used for making binder-less and resin bonded particleboard. 


\section{References}

ANSI A208.1 (2009), Particleboard. American National Standard. National Particleboard Association. Retrieved from www.bc.com/.../2014-Boise-CascadePB-vs-ANSI-A208-1-2009.

ASTM D 1037. (1999). Evaluating properties of wood-based fiber and particle panel materials. American Society for Testing and Measurement, Philadelphia, PA.

Das AK, Billha M, Shams MI and Hannan MO (2012), Physical and mechanical properties of bamboo wastage cement bonded board. Journal of the Indian Academy of Wood Science, 9:170-175, DOI 10.1007/s13196012-0084-1.

Das AK, Islam MA, Shams MI, Hannan MO and Biswas SK (2014), Physical and Mechanical Properties of UF Bonded and Without Binding Agent Bagasse MDF. Asian Journal of Applied Sciences, ISSN 19963343/DOI: 10.3923/ajaps.2014.45.40, 7(1):45-50.

Das AK, Mondal LR and Shams MI (2015), Physical and Mechanical Properties of Kenaf (Hibiscus cannabinus) MDF. Asian Journal of Applied Sciences, 8 (3): 204209, ISSN 1996 3343/DOI: 10.3923/ajaps. 2015. 204.209

Ghosh RK, Rahman MM, Das AK, Rana R and Shams MI (2015), Introducing Areca catechu as a raw material of cement-bonded board through determining the properties of Areca catechu cement-bonded board. Journal of the Indian Academy of Wood Science, 12(2):99-103, DOI 10.1007/s13196-015-0150-6.

Islam MS, Das AK, Ahmed MK and Shams MI (2013), Effects of $\mathrm{CaCl}_{2}$ and $\mathrm{NaHCO}_{3}$ on the physical and mechanical properties of Dhaincha (Sesbania aculeata) cement-bonded particleboard. Journal of the Indian Academy of Wood Science, DOI 10.1007/s13196-0130097-4 10(2):81-85.

Islam MI, Das AK, Zaman MS, Rana R and Shams MI (2014), Using of Rice Straw (Oryza sativa L.) for Better Purposes Fabricating and Evaluating of Physical and Mechanical Properties of Fiberboard. International Journal of Agricultural Science and
Technology, 2(3):93.DOI:10.14355/ijast.2014.0203.02.

Juliana AH, Paridah MT and Anwar UMK (2012), Properties of three-layer particleboards made from kenaf (Hibiscus cannabinus L.) and rubberwood (Hevea brasiliensis). Materials and Design, 40:59-63.

Jumhuri, N, Hashim, R, Sulaiman, O, Nadhari, WNAW, Salleh KM, Khalid I, Saharudin NI and Razali MZ (2014), Effect of treated particles on the properties of particleboard made from oil palm trunk. Materials and Design, 64: 769-774.

Lamaming J, Hashim R, Sulaiman O, Sugimoto T, Satoc M and Hiziroglu S (2014), Measurement of some properties of binderless particleboards made from young and old oil palm trunks. Measurement, 47 :813-819.

Maragatham DJ and Samuel PR (2010), Chemical characteristics of coir pith as a function of its particle size to be used as soilless medium. The ecoscan: an international quarterly journal of Environmental Science, 4(2 and 3):163-169.

Rahman MM, Das AK, Asaduzzaman M, Hannan MO and Biswas SK (2013), Physical and Mechanical Properties of Raj Koroi (Albizia Richardiana) Plywood. African Journal of Wood Science and Forestry. ISSN: 23267285 2(1): 098-103

Rahman MK, Asaduzzaman M, Rahman MM, Das AK and Biswas SK (2014), Physical and Mechanical Properties of Ghora Neem (Melia azedarach) Plywood. Bangladesh Journal of Scientific and Industrial Research, 49(1), 47-52. DOI: http://dx.doi.org/1 $0.3329 /$ bjsir.v49i1.18855.

Rashid MM, Das AK, Shams MI and Biswas SK (2014), Physical And Mechanical Properties of Medium Density Fiber Board (MDF) Fabricated From Banana Plant (Musa sapientum) Stem and Midrib. Journal of the Indian Academy of Wood Science, DOI 10.1007/s13196-014-0109-z. 11(1):1-4.

Saari N, Hashim R, Sulaiman O, Hiziroglu S, Sato M and Sugimoto T (2014), Properties of steam treated binderless particleboard made from oil palm trunks. Composites Part B 56:344-349. 
Sarkar M, Ashaduzzaman M, Das AK, Shams MI and Hannan MO (2012), Mechanical Properties and Dimensional stability of Cement Bonded Particleboard Made from Saw dust and Rice Husk. Bangladesh Journal of Scientific and Industrial Research, 47(3), 273-278.

Sellers T (2000), Growing markets for engineered products spurs research. Wood Technology, 127 (3):40-43.

van Dam, JEG (2002). Wet processing of coir drying, bleaching, dyeing, softening and printing. CFC/FAO Techno-economic manual No. 6.

van Dam JEG, van den Oever, MJA, Teunissen, W and Keijsers, ERP (2003), Process for production of high density / high performance binderless boards from whole coconut husk. Industrial Crops and Products, 20: 97-101, doi:10.1016/j.indcrop.2003.12.017.

van Dam JEG, van den Oever MJA, Teunissen, W, Keijsers, ERP and Peralta AG (2004), Process for production of high density / high performance binderless boards from whole coconut husk. Part 1. Lignin as intrinsic thermosetting binder resin. Industrial Crops and Products, 19(3): 207-216.

Yang HS, Kim DJ and Kim HJ (2003), Rice straw-wood particle composite for sound absorbing wooden construction materials. Bioresource Technology, 86(2):117-21.
Yossifov NA (1988), Mathematical modeling of parameters characterizing the gluing links between particles in particleboards. In: Mechanical Wood Technology. No.34 in Res. Pap. Series. Higher Inst. of Forestry and Wood Tech., Sofia, Bulgaria.

Youngquist JA (1999), Wood-based composites and panel products. In: Wood Hand book: Wood as an Engineering Material. Gen. Tech. Rept. FPL-GRT113. USDA Forest Serv., Forest Prod. Lab., Madison, WI, pp. 1-31.

Youngquist JA and Hamilton TE (2000), A look at the world's timber resources and processing facilities. In: Proceedings of the XXI IUFRO World Congress 2000, Sub-plenary sessions, vol. 1, Kuala Lumpur, Malaysia, pp. 183-190.

Zaman MS, Das AK, Shams MI, Rana R, Rahman, MM and Biswas SK (2013), Physical and mechanical properties of Agriculture plastic composite made from jute (Corchorus olitorius 1.) and dhaincha (Sesbania cannabina retz.). International Journal of Wood Science, Technology and Forestry, 1 (1): 001-008.

Received: 14 February 2015; Revised: 28 February 2016; Accepted: 24 April 2016. 